\title{
Front Matter: Volume 11548
}

, "Front Matter: Volume 11548," Proc. SPIE 11548, Optical Design and Testing X, 1154801 (6 November 2020); doi: 10.1117/12.2585941

SPIE. Event: SPIE/COS Photonics Asia, 2020, Online Only 


\title{
PROCEEDINGS OF SPIE
}

\section{Optical Design and Testing $X$}

\author{
Yongtian Wang \\ Tina E. Kidger \\ Osamu Matoba \\ Rengmao Wu \\ Editors
}

\section{1-16 October 2020 \\ Online Only, China}

Sponsored by

SPIE

COS-Chinese Optical Society

Cooperating Organizations

Tsinghua University (China) • Peking University (China) • University of Science and Technology of China (China) • Zhejiang University (China) • Tianjin University (China) • Beijing Institute of Technology (China) Beijing University of Posts and Telecommunications (China) • Nankai University (China) • Changchun University of Science and Technology (China) University of Shanghai for Science and Technology (China) $\bullet$ Capital Normal University (China) • Huazhong University of Science and Technology (China) • Beijing Jiaotong University (China) - China Jiliang University (China) - Shanghai Institute of Optics and Fine Mechanics, CAS (China) - Changchun Institute of Optics, Fine Mechanics and Physics, CAS (China) Institute of Semiconductors, CAS (China) • Institute of Optics and Electronics, CAS (China) • Institute of Physics, CAS (China) Shanghai Institute of Technical Physics, CAS (China) • China Instrument and Control Society (China) Japan Optical Society (Japan) • Korea Optical Society (Korea, Republic of) • Australia Optical Society (Australia) • Singapore Optical Society (Singapore) • European Optical Society

Supporting Organizations

China Association for Science and Technology (CAST) (China)

Department of Information of National Nature Science Foundation, China (NSFC) (China)

Published by

SPIE

Volume 11548 
The papers in this volume were part of the technical conference cited on the cover and title page. Papers were selected and subject to review by the editors and conference program committee. Some conference presentations may not be available for publication. Additional papers and presentation recordings may be available online in the SPIE Digital Library at SPIEDigitalLibrary.org.

The papers reflect the work and thoughts of the authors and are published herein as submitted. The publisher is not responsible for the validity of the information or for any outcomes resulting from reliance thereon.

Please use the following format to cite material from these proceedings:

Author(s), "Title of Paper," in Optical Design and Testing X, edited by Yongtian Wang, Tina E. Kidger, Osamu Matoba, Rengmao WU, Proceedings of SPIE Vol. 11548 (SPIE, Bellingham, WA, 2020) Sevendigit Article CID Number.

ISSN: 0277-786X

ISSN: 1996-756X (electronic)

ISBN: 9781510639119

ISBN: 9781510639126 (electronic)

Published by

SPIE

P.O. Box 10, Bellingham, Washington 98227-0010 USA

Telephone +1 3606763290 (Pacific Time) · Fax +1 3606471445

SPIE.org

Copyright (c) 2020, Society of Photo-Optical Instrumentation Engineers.

Copying of material in this book for internal or personal use, or for the internal or personal use of specific clients, beyond the fair use provisions granted by the U.S. Copyright Law is authorized by SPIE subject to payment of copying fees. The Transactional Reporting Service base fee for this volume is $\$ 21.00$ per article (or portion thereof), which should be paid directly to the Copyright Clearance Center (CCC), 222 Rosewood Drive, Danvers, MA 01923. Payment may also be made electronically through CCC Online at copyright.com. Other copying for republication, resale, advertising or promotion, or any form of systematic or multiple reproduction of any material in this book is prohibited except with permission in writing from the publisher. The CCC fee code is $0277-$ $786 \mathrm{X} / 20 / \$ 21.00$.

Printed in the United States of America by Curran Associates, Inc., under license from SPIE.

Publication of record for individual papers is online in the SPIE Digital Library.

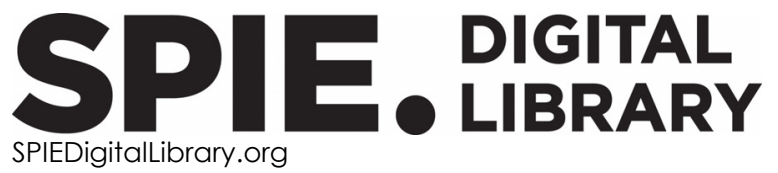

Paper Numbering: Proceedings of SPIE follow an e-First publication model. A unique citation identifier (CID) number is assigned to each article at the time of publication. Utilization of CIDs allows articles to be fully citable as soon as they are published online, and connects the same identifier to all online and print versions of the publication. SPIE uses a seven-digit CID article numbering system structured as follows:

- The first five digits correspond to the SPIE volume number.

- The last two digits indicate publication order within the volume using a Base 36 numbering system employing both numerals and letters. These two-number sets start with $00,01,02,03,04$, 05, 06, 07, 08, 09, OA, OB ... 0Z, followed by 10-1Z, 20-2Z, etc. The CID Number appears on each page of the manuscript. 


\section{Contents}

NOVEL IMAGING TECHNIQUES I

1154802 Transport of intensity phase imaging under a low signal-to-noise ratio condition (Invited Paper) [11548-1]

1154803 Multi-aperture 360-degree panoramic imaging for enhanced situational awareness (Invited Paper) [1 1548-2]

1154805 Modal-based adaptive autofocusing phase retrieval for wavefront measurement [11548-4]

1154806 Influences of aberrations on double random phase encoding system [1 1548-5]

1154807 The use of dual band anti-reflection (AR) black coatings in reducing stray light effect on IR camera system sharing aperture [1 1548-76]

NOVEL IMAGING TECHNIQUES II

11548 OA Helicity-multiplexed bifocal geometric metalenses at visible wavelength [1 1548-8]

11548 OCDesign of compensators for microscope lens [11548-10]

NOVEL DISPLAY AND IMAGING SYSTEMS

11548 OD Development of $x$-ray focusing telescope by thin-glass slumping technology (Invited Paper) [11548-11]

11548 OE Vehicle-mounted waveguide head-up display system based on reflective microprism [11548-13]

11548 OG Waveguide using grating coupler for uniform luminance and color AR display [11548-15]

\section{ILLUMINATION OPTICS}

$11548 \mathrm{OH}$ The development of automotive headlamp with blue laser and phosphor plate (Invited Paper) [11548-16]

11548 ol Analysis and suppression of stray radiation in an infrared telescope system in geosynchronous orbit [11548-17] 
$115480 \mathrm{~J}$ Design of compact and ultra-efficient aspherical lenses with prescribed irradiance characteristics for extended sources [11548-18]

11548 OK First optical design for wide angle micro LED without second lens [11548-19]

OPTICAL DESIGN AND TESTING

11548 OL Freeform surface measurement with non-null interferometry (Invited Paper) [11548-20]

11548 OM Aberration theory-based approaches to optical design (Invited Paper) [11548-21]

1154800 Research on the influence of the near vision area on the width of the astigmatism channel based on the minimization model [11548-23]

$11548 \mathrm{OP} \quad$ Network training parameters exploration for generating starting points of freeform reflective imaging system design based on machine learning [11548-24]

$11548 \mathrm{OQ}$ Wavefront measurement based on sparse aperture [11548-25]

INTERFEROMETRY AND HOLOGRAPHY

$11548 \mathrm{OR}$ 3D trajectory of minute object by parallel phase-shifting digital holographic microscope (Invited Paper) [1 1548-26]

11548 OS Design and prototyping of a multi-segment grating for broadband and miniaturized spectrometer (Invited Paper) [11548-27]

11548 OT Research on the influence of random refractive index medium on wave front detection in long optical path [11548-28]

11548 OU Virtual interferometer based on vector formula of ray tracing [11548-29]

$11548 \mathrm{OV}$ Measurement of refractive index of optical materials using improved Brewster method [11548-30]

INFORMATION OPTICS AND MICRO-OPTICS

11548 OW Problems of the realistic image synthesis in media with a gradient index of refraction [11548-31]

$115480 \mathrm{X}$ Investigation and evaluation of $\mathbf{2 5} \mathbf{~ G b} / \mathbf{s}$ optical modules for $\mathbf{5 G}$ fronthaul [1 1548-32]

$115480 Z$ Central core-assisted photon lantern with lower crosstalk and shorter length [11548-35]

iv 
1154810 A novel car panoramic system based on catadioptric structure with dual-band operating mode [11548-36]

\section{POSTER SESSION}

1154812 Composing method and aberration theory in collimating systems design [11548-38]

1154813 Design of off-axis reflective system with four mirrors based on freeform surface [11548-39]

1154814 Computer modelling of acousto-optical diffraction in optical systems design [11548-40]

1154815 Simultaneous measurement of two parameters of the spherical lens by low-coherence interferometry [11548-41]

1154816 Automated design of machine vision lens based on the combination of particle swarm optimization and damped least squares [11548-42]

1154818 Performance evaluation for imaging with a vortex half-wave retarder [11548-44]

1154819 Design and simulation of adaptive beam steering actuated by hydraulic polymer elastic membrane [11548-45]

11548 1A A full-parameter simulating software for closed loop fiber optic gyroscopes [11548-46]

11548 1B Test system for wafer-level silicon-photonics testing [11548-47]

11548 1D Reduction of polarization and spatio-temporal coherence of the light by using a moving rough-surfaced wave plate [11548-49]

$11548 \mathrm{lE} \quad$ Design of a MWIR spectral zoom imaging system [1 1548-50]

$11548 \mathrm{lF} \quad$ An innovative chemical mechanical polishing slurry for sesquioxides crystal (Yb:LuScO 3$)$ [11548-51]

11548 1G Design and fabrication of an ultra-thin under-display fingerprint sensor [11548-52]

$11548 \mathrm{1H}$ Solutions on global synthesis to improve multiple configurations [11548-53]

1154811 The bit error rate performance analysis of LDPC code in ultraviolet communication system [11548-54]

$11548 \mathrm{lJ} \quad$ Microlens design to explore biological tissues for parasitic diseases identification [1 1548-55]

$115481 \mathrm{~K} \quad$ Phase retrieval of vitreous floaters: simulation experiment [11548-56] 
$115481 \mathrm{~L} \quad$ Study on dwell time compensation method of atmospheric pressure plasma processing [11548-57]

$115481 \mathrm{M} \quad$ High-precision manufacturing technology of continuous phase plate based on magnetorheological finishing [11548-58]

$115481 Q$ Fusion of virtual and real scenes for the data preparation of holographic stereogram [1 1548-62]

11548 IR Preliminary assessment of estimated longitudinal chromatic aberration outside wavelength band [11548-63]

11548 is Virtual prototyping of imaging optics with HOE [11548-65]

11548 1T The efficient method of design optical element for low-intensity obstruction light [11548-66]

11548 IU A fluorescence detection optical system for real-time quantitative PCR [1 1548-67]

$115481 \mathrm{~V}$ Design of a compact and high-resolution image scanner with large depth-of-field based on compound eye system [11548-68]

11548 IW Optimized phase retrieval method base on multi-focus property of zone plate [11548-69]

$115481 \mathrm{X}$ Method for optimizing and evaluating ophthalmic lens based on inner aspheric lens-eye optical system [11548-70]

1154820 Classification and performance estimation of an intraocular lens with an orthogonal bidimensional refractive sinusoidal profile [11548-73]

1154821 A new integrated LED automotive headlight with laser supplement light [11548-74]

1154822 Stabilization of the spectral characteristics of reflective interference filters within a given range of angles of incidence [11548-75] 